[Article]

\title{
铁催化芳基格氏试剂的联芳交叉偶联的反应机理
}

\author{
任清华* 沈晓燕 \\ (上海大学理学院化学系, 上海 200444)
}

\begin{abstract}
摘要: 利用密度泛函理论(DFT)计算研究了 $\left[\mathrm{Fe}(\mathrm{MgBr})_{2}\right]$ 催化的邻氯苯乙稀与溴代苯基镁反应生成联芳化合物 的交叉偶联反应的机理. 研究了两个机理. 机理 A 包括三个基本步骤: (I) 氧化 [Fe( $\mathrm{MgBr})_{2}$ 生成 $[\mathrm{Ar}-\mathrm{Fe}(\mathrm{MgBr})]$, (II) 加成产生[Ar-(phenyl)-Fe(MgBr) 2$]$, (III) 还原消除回到[Fe(MgBr $)_{2}$. 机理 B 不形成 $[\mathrm{Ar}-\mathrm{Fe}(\mathrm{MgBr})]$. 在第一步, 溴代苯基镁在 $[\mathrm{Cl}-\mathrm{Mg}-\mathrm{Br}]$ 离解形成 $[\mathrm{Ar}-\mathrm{Fe}(\mathrm{MgBr})]$ 之前直接进攻氧化加成后的中间体. 考虑溶剂效应后, 机理 $\mathrm{B}$ 优于机理 $A$. 无论机理 $A$ 还是机理 $B$, 整个催化循环过程的决速步骤都是 $\left[A r-(\text { phenyl)-Fe(MgBr })_{2}\right.$ 的还原消除再 生催化剂 $\left[\mathrm{Fe}(\mathrm{MgBr})_{2}\right]$ 的步骤, 使用导体极化连续模型 (CPCM)方法计算其在四氢呋喃溶剂中的吉布斯自由能 $\left(\Delta G_{\text {so })}\right)$ 是 $82.98 \mathrm{~kJ} \cdot \mathrm{mol}^{-1}$.
\end{abstract}

关键词: 铁催化剂; 联芳; 交叉偶联; 反应机理; 密度泛函理论 中图分类号: 0641; 0643

\section{Reaction Mechanism for the Iron-Catalyzed Biaryl Cross-Coupling of Aryl Grignard Reagents}

\author{
REN Qing-Hua* SHEN Xiao-Yan \\ (Department of Chemistry, College of Science, Shanghai University, Shanghai 200444, P. R. China)
}

\begin{abstract}
Mechanisms for the $\left[\mathrm{Fe}(\mathrm{MgBr})_{2}\right]$ catalyzed cross-coupling reaction between ortho-chlorostyrene and phenylmagnesium bromide to form biaryl were studied using density functional theory (DFT) calculations. We investigated two mechanisms. Cycle A included three basic steps: (I) oxidation of $\left[\mathrm{Fe}(\mathrm{MgBr})_{2}\right]$ to obtain $[\mathrm{Ar}-$ $\mathrm{Fe}(\mathrm{MgBr})]$, (II) addition to yield [Ar-(phenyl)-Fe( $\left.\mathrm{MgBr})_{2}\right]$, and (III) reductive elimination to return to $\left[\mathrm{Fe}(\mathrm{MgBr})_{2}\right]$. Cycle $\mathrm{B}$ did not form $[\mathrm{Ar}-\mathrm{Fe}(\mathrm{MgBr})]$. In the first step, phenylmagnesium bromide attacks the intermediate of the oxidative addition directly before [Cl-Mg-Br] dissociates to form [Ar- $\mathrm{Fe}(\mathrm{MgBr})]$. The catalytic $\mathrm{Cycle} \mathrm{B}$ is favored over the catalytic Cycle A when considering the solvent effect. The rate-limiting step in the overall catalytic cycle for both Cycle $A$ and Cycle $B$ is the reductive elimination of $\left[\mathrm{Ar}\right.$-(phenyl)-Fe $\left.(\mathrm{MgBr})_{2}\right]$ to regenerate the catalyst $\left[\mathrm{Fe}(\mathrm{MgBr})_{2}\right]$, where the Gibbs free energy in solvent tetrahydrofuran (THF), $\Delta G_{\text {sol, }}$, is $82.98 \mathrm{~kJ} \cdot \mathrm{mol}^{-1}$, as determined using the conductor polarized continuum model (CPCM) method.
\end{abstract}

Key Words: Iron catalyst; Biaryl; Cross-coupling; Reaction mechanism; Density functional theory

\section{Introduction}

Transition metal-catalyzed cross-coupling reactions are of utmost importance for the formation of carbon-carbon as well as carbon-heteroatom bonds. In general, palladium and nickel catalysts dominate this field, such as, Negishi, ${ }^{1,2}$ Suzuki, ${ }^{3,4}$ Heck, ${ }^{5,6}$
Stille, ${ }^{7,8}$ and Kumada-Corriu ${ }^{9-11}$ reactions. The biaryl compounds are very important intermediates in modern organic synthesis and pharmaceutical products. ${ }^{12}$ Palladium- and nickel-catalyzed crosscoupling reactions are among the most versatile methods for the synthesis of biaryl compounds. Suzuki-Miyaura reactions between

Received: December 25, 2014; Revised: February 9, 2015; Published on Web: March 2, 2015.

"Corresponding author. Email: qinghua.ren@shu.edu.cn; Tel: +86-21-66132404; Fax: +86-21-66134594.

The project was supported by the High Performance Computing Platform of Shanghai University, China and Shanghai Higher Education Connotation Construction “085” Project “Materials Genome Engineering” Funding, China (B.58-B111-12-101, B.58-B111-12-103).

上海大学高性能计算平台“自强 4000”与上海市高等教育内涵建设“085”工程“材料基因工程”项目(B.58-B111-12-101, B.58-B111-12-103)资助

(C) Editorial office of Acta Physico-Chimica Sinica 
arylboronic acids and aryl halides are widely applied because of their especially mild conditions and excellent compatibility with many functional groups. ${ }^{13-16}$ However, palladium and nickel catalysts are limited by the high price or considerable toxicity, especially for industrial processes. Iron-catalyzed cross-coupling reactions have become increasingly important in the construction of complex molecular frameworks in the last few decades due to their high efficiency, cheapness, non-toxicity, and the environmental health of the simple iron salt precatalysts. ${ }^{17-20}$ The complex, airsensitive ligands are also not required and the mild reaction conditions tolerate various functional groups.

Furstner et al. ${ }^{21,22}$ reported a lot of highly selective iron-catalyzed cross-coupling reactions of aryl halides with alkyl magnesium halides and the iron-catalyzed cross-coupling reactions have matured into a class of effective carbon-carbon as well as carbon-heteroatom bond-forming reactions. ${ }^{23-27}$ In general, the iron-catalyzed biaryl syntheses from aryl Grignard species and aryl halides are proved unselective. ${ }^{22,28-30}$ For example, Hatakeyama et al. ${ }^{31,32}$ reported a method which requires a special precatalyst combination of iron(II) fluoride and a carbine ligand and also needs the generation of the catalytically active species in a prior step to improve the selectivity.

Later, von Wangelin et al. ${ }^{33}$ paid attention to many papers ${ }^{34,35}$ about the rich coordination abilities of olefins with iron in low oxidation states and proposed a new method of activation for olefin-substituted aryl chlorides. The sequential olefin coordination at the catalyst and haptotropic migration could affect $\mathrm{C}-$ $\mathrm{Cl}$ bond activation of chlorostyrenes. ${ }^{36}$ They had reported an efficient iron-catalyzed biaryl synthesis where the reaction of aryl Grignard species with chlorostyrenes proceeded under mild reaction conditions in the presence of iron(III) tris(acetylacetonate) $\left[\mathrm{Fe}(\mathrm{acac})_{3}\right]$ as precatalyst. ${ }^{36}$

The theoretical understanding of the reaction mechanisms of the transition metal-catalyzed processes may shed light on how to design more powerful catalysts and how to control the catalysis process. However, the mechanisms of the iron-catalyzed reactions remain rather obscure. Kochi, ${ }^{37}$ Furstner, ${ }^{20,22}$ Bogdanovic, ${ }^{38}$ Norrby, ${ }^{39}$ et al. have reported some mechanisms of iron-catalyzed crosscoupling reactions of Grignard reagents. Our group ${ }^{40}$ have investigated the mechanisms of iron-catalyzed cross-coupling reactions of alkyl Grignard reagents using density functional theory calculations.

The catalyzed cycles start form the inorganic Grignard reagent $\left[\mathrm{Fe}(\mathrm{MgX})_{2}\right]$, where $\mathrm{X}=\mathrm{Br}$ or $\mathrm{I}$. $\left[\mathrm{Fe}(\mathrm{MgX})_{2}\right]$ consists of two magnesium atoms and one iron center that are connected via two covalent intermetallic bonds. It was generally used to explain many of the experimental results by Furstner et al, ${ }^{20-22}$ where the initial $\left[\mathrm{Fe}(\mathrm{MgX})_{2}\right]$ is formed from the iron precatalyst and $\mathrm{RMgX}$. The mechanism is through $\mathrm{Fe}(-\mathrm{II})$ and $\mathrm{Fe}(0)$ catalytic cycle, where the iron center is $\mathrm{Fe}(-\mathrm{II})$ in $\left[\mathrm{Fe}(\mathrm{MgX})_{2}\right]$, and $\mathrm{Fe}(0)$ in $\left[{ }^{1} \mathrm{R}-\right.$ $\mathrm{Fe}(\mathrm{MgX})]$ and $\left[{ }^{1} \mathrm{R}-\left({ }^{2} \mathrm{R}\right)-\mathrm{Fe}(\mathrm{MgX})_{2}\right]$. The multiplicity of Fe is set as 1 . As far as we know, detailed theoretical studies concerning the $\left[\mathrm{Fe}(\mathrm{MgX})_{2}\right]$ catalyzed biaryl cross coupling processes of aryl
Grignard reagents have not yet been performed, although the experimental results involving iron-catalyzed cross-coupling of aryl Grignard reagents have recently been reported. . $^{41,42}$

Here, we select one typical reaction in the experimental work of Gulak and von Wangelin ${ }^{36}$ as an example, which is depicted in Scheme 1, in order to gain insight into the mechanisms of ironcatalyzed cross-coupling reactions of aryl Grignard reagents. The experimental reaction was carried out in tetrahydrofuran (THF) $/ \mathrm{N}$ methyl-2-pyrrolidone (NMP) using $\mathrm{Fe}(\mathrm{acac})_{3}(5 \%$, molar fraction) as the precatalyst. $\mathrm{Fe}(\mathrm{acac})_{3}$ reacts with $\mathrm{R}-\mathrm{MgBr}$ to yield the inorganic Grignard reagent $\left[\mathrm{Fe}(\mathrm{MgBr})_{2}\right]$, which is readily soluble in THF. Our thorough theoretical investigation is applied to $\left[\mathrm{Fe}(\mathrm{MgBr})_{2}\right]$ catalyzed cross-coupling reaction between orthochlorostyrene [Cl-Ph-vinyl] and phenylmagnesium bromide $[\mathrm{PhMgBr}]$ using density functional theory (DFT) calculations with the B3LYP method. ${ }^{43-48}$

We will study two mechanisms. One mechanism is named as Cycle A with forming [Ar-Fe( $\mathrm{MgBr})]$ in the catalytic cycle and another mechanism is named as Cycle B without forming [Ar-Fe $(\mathrm{MgBr})]$ in the catalytic cycle. Our theoretical studies will answer the questions: Which catalytic cycle is favored? Which step is the rate-determining step in the whole catalytic cycle? Is it possible to lower the energy barrier when considering the solvent effect? Answers to these questions will improve the understanding of ironcatalyzed cross-coupling of aryl Grignard reagents.

\section{Computational methods}

All DFT calculations were performed using the Gaussian 03 program ${ }^{49}$ with the B3LYP hybrid functional. ${ }^{43-48}$ The $6-311++\mathrm{G}(d$, p) basis set was used for $\mathrm{C}, \mathrm{H}, \mathrm{Cl}, \mathrm{Br}$, and $\mathrm{Mg} .{ }^{50,51}$ The SDD quasirelativistic pseudopotential and associated basis set was used for iron. $^{52}$ All equilibrium structures of the gas phase geometries were fully optimized without any symmetry restriction and then the vibrational frequencies analysis was performed to ensure that the local minima had zero imaginary frequencies and the transition state had exactly one. The solvent effect was calculated using the conductor polarized continuum model (CPCM) method $^{53}$ with the UFF radii on the gas-phase optimized geometries. The polarizable continuum model (PCM) is a commonly used method in computational chemistry to model salvation effects. It models the solvent as a polarizable continuum, rather than individual molecules, which has two popular types: dielectric PCM (DPCM) and conductor-like PCM (CPCM). Both the electronic and nonelectronic free energies in solution were added to the gas-phase Gibbs free energies to obtain the solution Gibbs free energies in THF, $\Delta G_{\text {sol. }}{ }^{40}$ All the solution-phase free energies reported in the paper

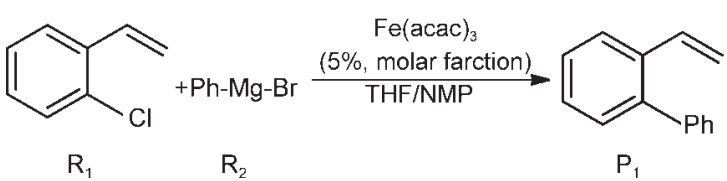

Scheme 1 Iron-catalyzed cross-coupling reaction between ortho-chlorostyrene and phenylmagnesium bromide 
correspond to the reference state of $1 \mathrm{~mol} \cdot \mathrm{L}^{-1}, 298 \mathrm{~K}$.

\section{Results and discussion}

\subsection{Catalytic Cycle A with forming [Ar-Fe(MgBr)]}

The catalytic cycle A is similar as the mechanistic proposal of Furstner et al., ${ }^{22}$ which is outlined in Fig.1. It includes three basic steps: (I) oxidation of [ $\left.\mathrm{Fe}(\mathrm{MgBr})_{2}\right]$ to obtain [Ar-Fe( $\left.\left.\mathrm{MgBr}\right)\right]$, (II) addition with phenylmagnesium bromide to yield [Ar-(phenyl)$\left.\mathrm{Fe}(\mathrm{MgBr})_{2}\right]$, and (III) reductive elimination to return to $\left[\mathrm{Fe}(\mathrm{MgBr})_{2}\right]$. The cycle A includes three transition states $\left(\mathrm{TS}_{1}, \mathrm{TS}_{2}, \mathrm{TS}_{3}\right)$. The fully optimized structures of the reactant $R_{1}$, the catalyst $C A$, the complex $\mathbf{2}$, the transition state $\mathrm{TS}_{1}$, the intermediates $\mathbf{3}$ and $\mathbf{4}$, and the product $\mathrm{P}_{2}$ are shown in Fig.2. The fully optimized geometries of the reactant $R_{2}$, the complex 5 , the transition states $\mathrm{TS}_{2}, \mathrm{TS}_{3}$, the intermediate 6, and the final product $\mathrm{P}_{1}$ are shown in Fig.3. The values of the bonding distances (the unit is $\mathrm{nm}$ ) are also given in Figs. 2 and 3.

(I) oxidation of $\left[\mathrm{Fe}(\mathrm{MgBr})_{2}\right]$ to obtain $[\mathrm{Ar}-\mathrm{Fe}(\mathrm{MgBr})]$. The approach of $\mathrm{R}_{1}$ toward the catalyst $\mathrm{CA},\left[\mathrm{Fe}(\mathrm{MgBr})_{2}\right]$, leads to the formation of a complex $\mathbf{2}$. From $\mathbf{2}$, after passing through a transition state $\mathrm{TS}_{1}$, the intermediate $\mathbf{3}$ of oxidative addition is obtained. In the optimized geometry of $\mathbf{2}$ (see Fig.2), the iron atom is above the center of the phenyl and is far from the ${ }^{1} \mathrm{C}-\mathrm{Cl}$ bond. The distances of ${ }^{1} \mathrm{C}-\mathrm{Fe}$ and $\mathrm{Cl}-\mathrm{Fe}$ are 0.207 and $0.342 \mathrm{~nm}$, respectively. Then in the transition state $\mathrm{TS}_{1}$, the chlorine atom approaches toward ${ }^{2} \mathrm{Mg}$ atom around the iron center departing from ${ }^{1} \mathrm{C}$ atom. The distance of $\mathrm{Cl}-\mathrm{Fe}$ is $0.239 \mathrm{~nm}$. It becomes $0.224 \mathrm{~nm}$ in the optimized geometry of $\mathbf{3}$, accompanying with the formation of $\mathrm{Cl}^{2}{ }^{2} \mathrm{Mg}$ bond (0.242 nm, see Fig.2). At the same time, the distance of $\mathrm{Fe}-{ }^{2} \mathrm{Mg}$ increases from $0.253 \mathrm{~nm}$ in the optimized structure of $\mathbf{2}$ to $0.260 \mathrm{~nm}$ in the optimized structure of

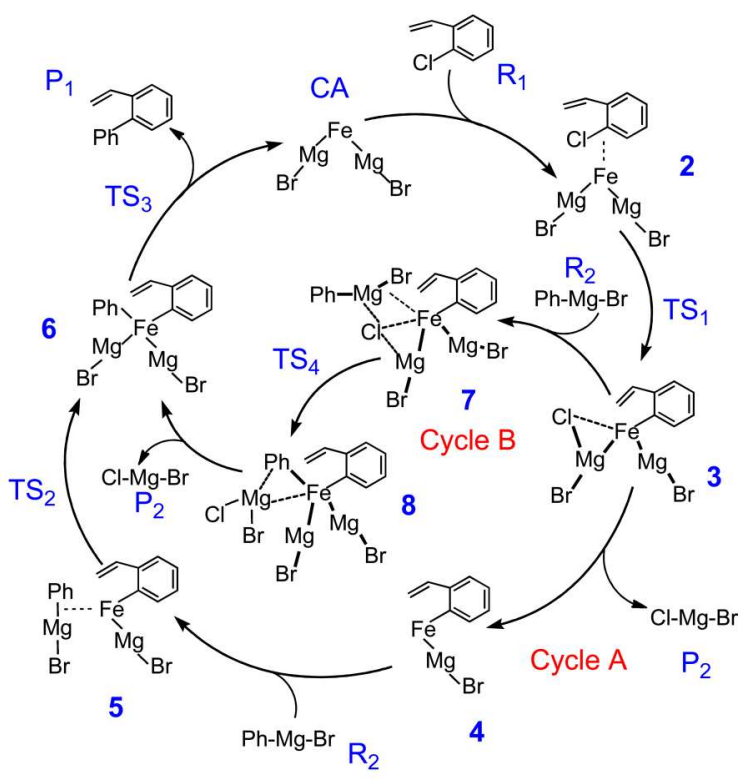

Fig.1 Outline of the iron-catalyzed cross-coupling reaction mechanism for the product $P_{1}$ from ortho-chlorostyrene $\mathbf{R}_{1}$ and phenylmagnesium bromide $\mathbf{R}_{2}$

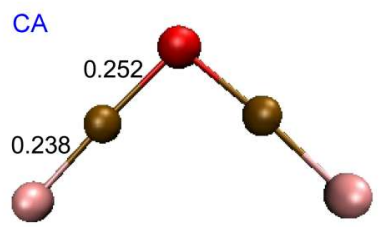

$\mathrm{R}_{1}$
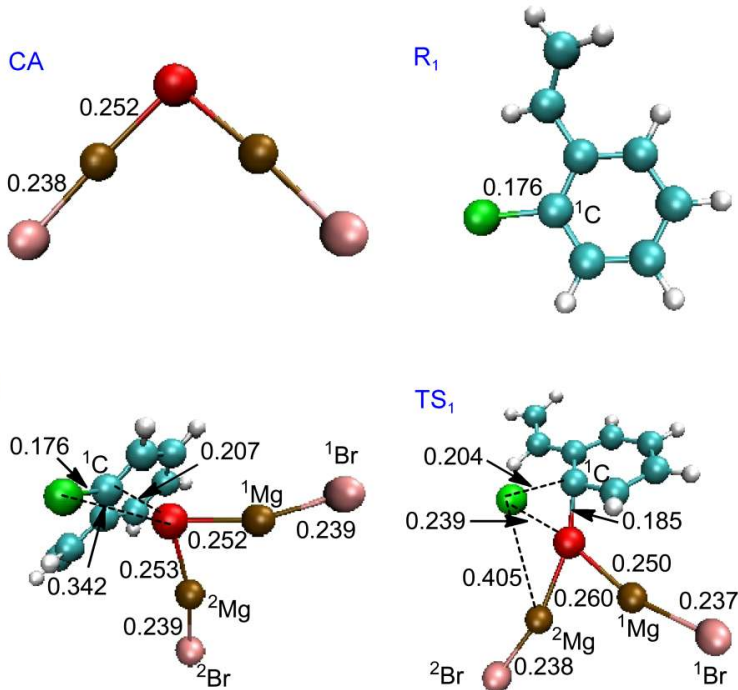

3

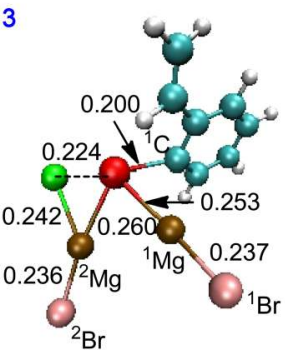

$\mathrm{P}_{2}$
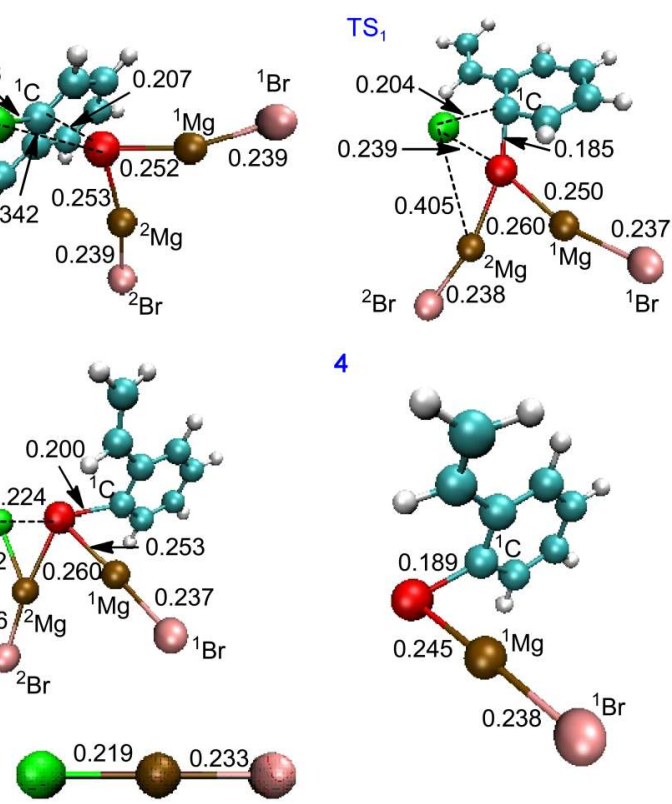

4

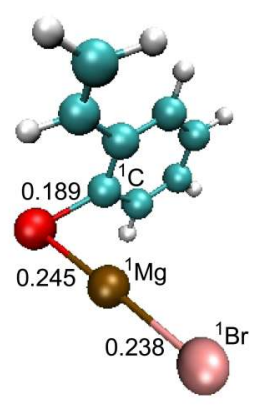

Fig.2 Fully optimized structures of the reactant $R_{1}$, the catalyst $\mathrm{CA}$, the intermediates $2,3,4$, the transition state $\mathbf{T S}_{1}$, and the product $\mathrm{P}_{2}$

The unit of the distance is nm. C: cyan, $\mathrm{H}$ : white, Fe: red, $\mathrm{Mg}$ : ochre, $\mathrm{Br}$ : pink, $\mathrm{Cl}$ : green. Colors refer to the web version of this article.

3 because of the bonding of $\mathrm{Cl}$ atom with the ${ }^{2} \mathrm{Mg}$ atom and the interaction of $\mathrm{Cl}$ atom with $\mathrm{Fe}$ atom. The weakening process of the bonding of $\mathrm{Fe}-{ }^{2} \mathrm{Mg}$ is beneficial for the further reaction, i.e., the covalent intermetallic bonding of $\mathrm{Fe}-{ }^{2} \mathrm{Mg}$ breaks and the molecule $\mathrm{P}_{2}$ dissociates from 3 to form the intermediate 4 , [(BrMg)-Fe-(Ph-vinyl)]. The bond distances of ${ }^{1} \mathrm{C}-\mathrm{Fe}$ and $\mathrm{Fe}-$ ${ }^{1} \mathrm{Mg}$ in the optimized structure of 4 are 0.189 and $0.245 \mathrm{~nm}$, respectively.

(II) Addition of another reactant phenylmagnesium bromide $\mathrm{R}_{2}$ to 4 yields the intermediate 6, $\left[\mathrm{Ar}-(\mathrm{Ph}-)-\mathrm{Fe}(\mathrm{MgBr})_{2}\right]$. After the intermediate $\mathbf{4}$ is formed, the approach of $\mathrm{R}_{2}$ toward $\mathbf{4}$, leads to the formation of a complex 5. From 5, passing through a threemembered-ring transition state $\mathrm{TS}_{2}$, the intermediate $\mathbf{6}$ is formed. From the fully optimized structures of $\mathbf{5}, \mathrm{TS}_{2}$ and $\mathbf{6}$ shown in Fig.3, it can be seen that the $\mathrm{Fe}-{ }^{2} \mathrm{Mg}$ distance is $0.267 \mathrm{~nm}$ in $\mathrm{TS}_{2}$, compared to that of $0.277 \mathrm{~nm}$ in $\mathbf{5}$. The distance of $\mathrm{Fe}-{ }^{2} \mathrm{C}$ also decreases from $0.439 \mathrm{~nm}$ in $\mathbf{5}$ to $0.354 \mathrm{~nm}$ in $\mathrm{TS}_{2}$, so that it is easy for atom ${ }^{2} \mathrm{C}$ to attack $\mathrm{Fe}$ atom in $\mathrm{TS}_{2}$, leading to the formation of a $\mathrm{Fe}-{ }^{2} \mathrm{C}$ bond to obtain the intemediate 6 . The bond distance of $\mathrm{Fe}-{ }^{2} \mathrm{C}$ in 6 is $0.189 \mathrm{~nm}$.

(III) Finally, reductive elimination of $\mathbf{6}$ to return to the catalyst 

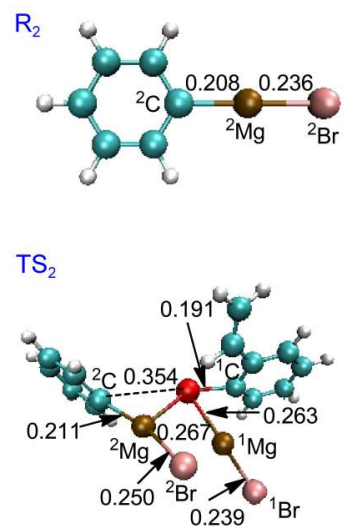

$\mathrm{TS}_{3}$
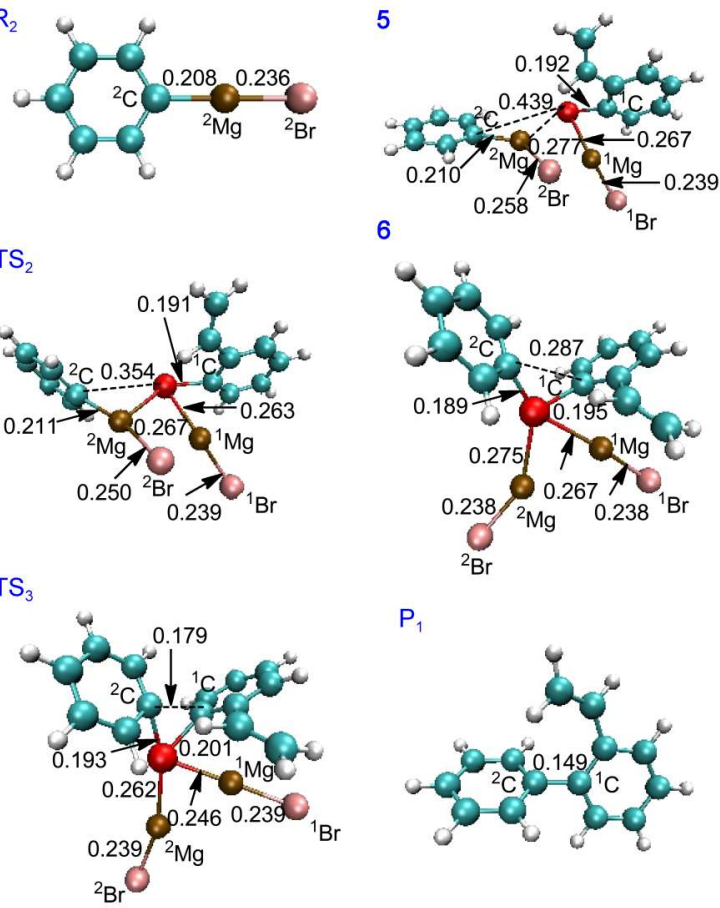

$P_{1}$

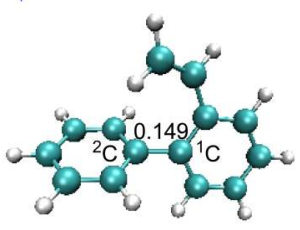

Fig.3 Fully optimized structures of the reactant $R_{2}$, the intermediates 5, 6, the transition states $\mathrm{TS}_{2}, \mathrm{TS}_{3}$, and the final product $P_{1}$

The unit of the distance is nm. C: cyan, H: white, Fe: red, Mg: ochre, $\mathrm{Br}$ : pink, $\mathrm{Cl}$ : green. Colors refer to the web version of this article.

$\mathrm{CA},\left[\mathrm{Fe}(\mathrm{MgBr})_{2}\right]$. This process passes through the third transition state $\mathrm{TS}_{3}$ to form the product $\mathrm{P}_{1},[\mathrm{Ph}-\mathrm{Ph}$-vinyl $]$ and to regenerate the original catalyst $\mathrm{CA}$. From the fully optimized structures of $\mathbf{6}$, $\mathrm{TS}_{3}$, and $\mathrm{P}_{1}$ shown in Fig. 3 , the ${ }^{2} \mathrm{C}$ and ${ }^{1} \mathrm{C}$ atoms in $\mathrm{TS}_{3}$ go closer to $0.179 \mathrm{~nm}$ from $0.287 \mathrm{~nm}$ in 6 and finally the bond of ${ }^{2} \mathrm{C}-{ }^{1} \mathrm{C}$ is formed in $\mathrm{P}_{1}(0.149 \mathrm{~nm})$.

The electronic energy profiles for the whole catalytic cycles for iron-catalyzed cross-coupling reaction between ortho-chlorostyrene and phenylmagnesium bromide are depicted in Fig.4, where the summation of the electronic energies of the reactant $R_{1}$ and the catalyst CA is set as zero energy.

From Fig.4, it can be seen that the energy barrier from the complex 2 to the first transition state $\mathrm{TS}_{1}$ is $106.11 \mathrm{~kJ} \cdot \mathrm{mol}^{-1}$. The energy value needed for the process in which the molecule $\mathrm{P}_{2}$, [Cl$\mathrm{Mg}-\mathrm{Br}$ ], dissociates from the intermediate 3 to form the intermediate 4 is $115.16 \mathrm{~kJ} \cdot \mathrm{mol}^{-1}$. It refers to the breaking of the strong covalent intermetallic bonding of $\mathrm{Mg}-\mathrm{Fe}$. This could be offset by the large exothermicity $\left(-139.64 \mathrm{~kJ} \cdot \mathrm{mol}^{-1}\right)$ process forming the intermediate $\mathbf{3}$ from $\mathbf{2}$. The transition state connecting 3 and $\mathbf{4}$ has not been found after many attempts. The energy barrier of $\mathrm{TS}_{2}$ from 5 to form a stable structure $\mathbf{6}$ [Ar-(phenyl)$\left.\mathrm{Fe}-(\mathrm{MgBr})_{2}\right]$ is small $\left(4.87 \mathrm{~kJ} \cdot \mathrm{mol}^{-1}\right)$.

The energy barrier of $\mathrm{TS}_{3}$ to form the final product $\mathrm{P}_{1}$ from the intermediate 6 when releasing the catalyst CA through the reductive elimination is $96.47 \mathrm{~kJ} \cdot \mathrm{mol}^{-1}$. This process is needed to break two $\mathrm{Fe}-\mathrm{C}$ bonds. In all, the energy barriers for the steps of $\mathbf{2} \rightarrow \mathbf{3}, \mathbf{3} \rightarrow \mathbf{4}$ and $\mathbf{6} \rightarrow \mathrm{CA}+\mathrm{P}_{1}$ are closer and the step of $\mathbf{3} \rightarrow \mathbf{4}$ is the

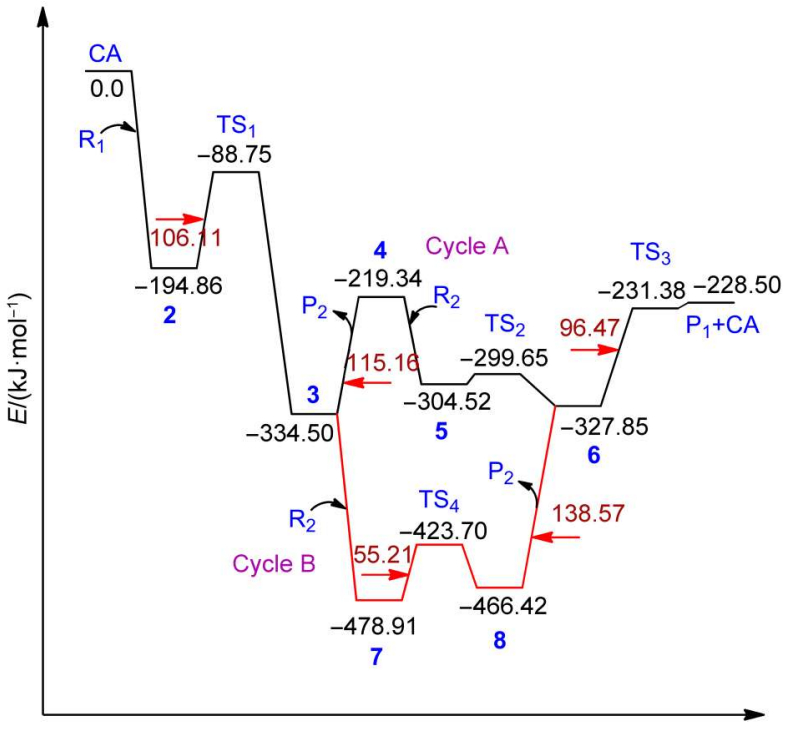

Fig.4 Electronic energy profiles for the overall catalytic cycles of the iron-catalyzed cross-coupling reaction

rate-limiting step in the whole catalytic cycle of the mechanism of Cycle A for the gas calculation.

\subsection{Catalytic cycle B without forming [Ar-Fe(MgBr)]}

Considering that the required electronic energy for the process in which the molecule $\mathrm{P}_{2},[\mathrm{Cl}-\mathrm{Mg}-\mathrm{Br}]$ dissociates from the intermediate 3 to form the intermediate 4 is very high by $115.16 \mathrm{~kJ}$. $\mathrm{mol}^{-1}$ (see Fig.4), it could be possible that there is another way to lower the energy barrier, namely if phenylmagnesium bromide $\left(\mathrm{R}_{2}\right)$ attacks the intermediate 3 directly before the formation of $\mathbf{4}$, [Ar- $\mathrm{Fe}(\mathrm{MgBr})]$. Our previous calculations ${ }^{40}$ about $\left[\mathrm{Fe}(\mathrm{MgBr})_{2}\right]$ catalyzed cross-coupling reaction between 4-chlorobenzoic acid methyl ester and $n$-hexylicmagnesium bromide have proved that the new path is easier than the catalytic cycle A with forming [Ar$\mathrm{Fe}(\mathrm{MgBr})]$. We did the similar calculations for the reaction between ortho-chlorostyrene and phenylmagnesium bromide. The catalytic cycle is named as cycle B, which is also shown in Fig.1.

From Fig.1, it can be seen that the reactant $R_{2}$ firstly approaches toward the intermediate 3 to form the complex 7. From 7, after passing through one transition state $\mathrm{TS}_{4}$, an intermediate $\mathbf{8}$ is formed. The fully optimized structures of $7, \mathrm{TS}_{4}$ and $\mathbf{8}$ in the gas phase are shown in Fig.5. Then the molecule $\mathrm{P}_{2}$ dissociates from the intermediate 8 to yield 6 . In the optimized geometry of 7, the distance of $\mathrm{Cl}-{ }^{3} \mathrm{Mg}$ is $0.245 \mathrm{~nm}$. The $\mathrm{Cl}-{ }^{2} \mathrm{Mg}$ bond length becomes longer to $0.264 \mathrm{~nm}$ compared to that of $0.242 \mathrm{~nm}$ in 3 , which means that the $\mathrm{Cl}$ atom is now linked to the ${ }^{3} \mathrm{Mg}$ atom. The distance of $\mathrm{Cl}$ with $\mathrm{Fe}$ also becomes longer to $0.241 \mathrm{~nm}$, compared to that of $0.224 \mathrm{~nm}$ in 3 . The distances of $\mathrm{Fe}-{ }^{3} \mathrm{Br}$ and $\mathrm{Fe}-$ ${ }^{3} \mathrm{Mg}$ are $0.250,0.345 \mathrm{~nm}$, respectively. Next, the atom ${ }^{3} \mathrm{Br}$ in 7 rotates around the ${ }^{3} \mathrm{Mg}$ atom to bring the atom ${ }^{2} \mathrm{C}$ close to the $\mathrm{Fe}$ atom, so that the atom ${ }^{2} \mathrm{C}$ can attack the Fe center easily. In the optimized structure of the transition state $\mathrm{TS}_{4}$, the distance of atom ${ }^{2} \mathrm{C}$ from the $\mathrm{Fe}$ atom is $0.258 \mathrm{~nm}$. It becomes shorter to $0.201 \mathrm{~nm}$ in the optimized structure of $\mathbf{8}$, which is close to the value of $0.189 \mathrm{~nm}$ in the optimized structure of 6 (see Fig.3). The distances 
7
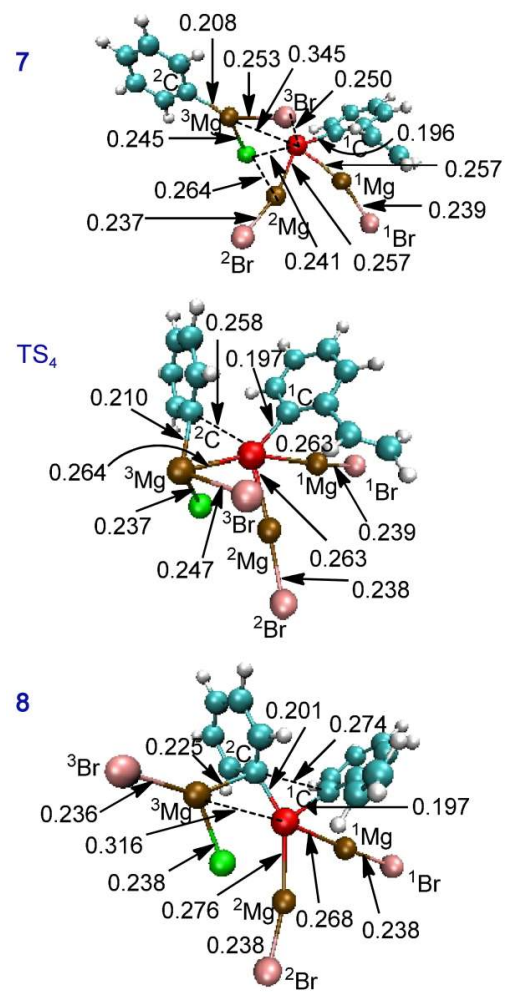

Fig.5 Fully optimized structures of the intermediates 7, 8 and transition state $\mathrm{TS}_{4}$ for the Cycle $\mathrm{B}$

The unit of the distances is nm. C: cyan, H: white, Fe: red, Mg: ochre, Br: pink, $\mathrm{Cl}$ : green. Colors refer to the web version of this article.

of ${ }^{2} \mathrm{C}-{ }^{3} \mathrm{Mg}$ and $\mathrm{Fe}-{ }^{3} \mathrm{Mg}$ become longer to $0.225,0.316 \mathrm{~nm}$ in $\mathbf{8}$, compared to those of $0.210,0.264 \mathrm{~nm}$ in $\mathrm{TS}_{4}$, respectively. It is beneficial for the process in which the molecule $\mathrm{P}_{2}$ dissociates from the intermediate $\mathbf{8}$ to yield $\mathbf{6}$.

The electronic energy profile from the intermediate $\mathbf{3}$ to the intermediate 6 for Cycle B is also depicted in Fig.4. From Fig.4, it can be seen that the energy barrier to pass over the transitional state $\mathrm{TS}_{4}$ is only $55.21 \mathrm{~kJ} \cdot \mathrm{mol}^{-1}$, which is much smaller than $115.16 \mathrm{~kJ} \cdot \mathrm{mol}^{-1}$ required when the molecule $\mathrm{P}_{2}$, [Cl-Mg- $\left.\mathrm{Br}\right]$ dissociates directly from the intermediate $\mathbf{3}$ before another reac$\operatorname{tant} \mathrm{R}_{2}$ attacks. However, the energy needed for the process when the molecule $\mathrm{P}_{2},[\mathrm{Cl}-\mathrm{Mg}-\mathrm{Br}]$ dissociates from the intermediate 8 to form 6 is very high, i.e., $138.57 \mathrm{~kJ} \cdot \mathrm{mol}^{-1}$. It looks that the Cycle B is not favored than Cycle A for the gas phase calculations, which is different from the previous calculations about $\left[\mathrm{Fe}(\mathrm{MgBr})_{2}\right]$ catalyzed cross-coupling reaction between $n$-hexylicmagnesium bromide and 4-chlorobenzoic acid methyl ester. ${ }^{40}$

\subsection{Solvent effect}

All of the above results are calculated in the gas phase. According to our previous study about $\left[\mathrm{Fe}(\mathrm{MgBr})_{2}\right]$ catalyzed crosscoupling reaction between 4-chlorobenzoic acid methyl ester and $n$-hexylicmagnesium bromide, ${ }^{40}$ the CPCM method is suitable to calculate the solvent effect for the iron-catalyzed cross-coupling reactions of alkyl Grignard reagents. Now we used the same $\mathrm{CPCM}$ method to investigate the solvent effect for the $\left[\mathrm{Fe}(\mathrm{MgBr})_{2}\right]$ catalyzed cross-coupling reaction between ortho-chlorostyrene and phenylmagnesium bromide. In order to clarify whether the solvent effect can play a significant role in the process, we compare the Gibbs free energies $\Delta G_{\mathrm{g}}$ and the Gibbs free energies in THF solution, $\Delta G_{\mathrm{sol}}$ for the overall catalytic cycles of two mechanisms (Cycle A and Cycle B), which are shown in Fig.6. The former is depicted as the solid line and the latter is drawn as the dashed line.

From Fig.6, it can be seen that the solvent effect is very obvious for the steps of dissociating $\mathrm{P}_{2}$ from 3 to form $\mathbf{4}$ in the Cycle $\mathrm{A}$ or from 8 to obtain 6 in the Cycle B. $\Delta G_{\text {sol }}(3 \rightarrow 4)$ is $-55.94 \mathrm{~kJ} \cdot \mathrm{mol}^{-1}$ compared that $\Delta G_{\mathrm{g}}(\mathbf{3} \rightarrow \mathbf{4})$ is $67.02 \mathrm{~kJ} \cdot \mathrm{mol}^{-1}$, Similarly, $\Delta G_{\text {sol }}(\mathbf{8} \rightarrow$ 6) is $-17.00 \mathrm{~kJ} \cdot \mathrm{mol}^{-1}$ compared that $\Delta G_{\mathrm{g}}(\mathbf{8} \rightarrow \mathbf{6})$ is $86.69 \mathrm{~kJ} \cdot \mathrm{mol}^{-1}$. The solvent effect is exothermic.

The solvent effect causes large changes of the $\Delta G$ values for the processes of $(\mathbf{3} \rightarrow \mathbf{4})$ in the Cycle A and of $(\mathbf{8} \rightarrow \mathbf{6})$ in the Cycle B. As far as we know, the solute is placed in a cavity in the solvent using CPCM method. The free energy of solvation was calculated from the surface charges of the solute and their interactions with the solvent. ${ }^{40,54}$ In general, the solvent effect is large for the dissociation processes because the gas phase calculations strongly favor the formation of clusters and make dissociation reactions more difficult than in condensed phases. ${ }^{40,54-56}$ For example, Schubert and Papai $^{57}$ has reported that the solvent effect was large for the process of dissociation of a $\mathrm{PMe}_{3}$ ligand in the $\mathrm{C}-\mathrm{C}$ coupling. Other calculations reported by Castellani et al. ${ }^{58}$ also showed that the solvent effect can change the dissociation energy value from $332.31 \mathrm{~kJ} \cdot \mathrm{mol}^{-1}$ in the gas phase to $168.45 \mathrm{~kJ} \cdot \mathrm{mol}^{-1}$ within the toluene solvent for the process of dissociation of $\mu-\mathrm{CH}_{3}$ contact ion-pair.

We can see that the energy barrier $\Delta G_{\text {sol }}$ from 4 through 5 to $\mathrm{TS}_{2}$ in THF solvent during the process from $\mathbf{3}$ to $\mathbf{6}$ for Cycle A is 39.76 $\mathrm{kJ} \cdot \mathrm{mol}^{-1}$. However, the energy barrier $\Delta G_{\text {sol }}$ from 7 through $\mathrm{TS}_{4}$ to $\mathbf{8}$ in THF solvent during the process from $\mathbf{3}$ to $\mathbf{6}$ for Cycle B is

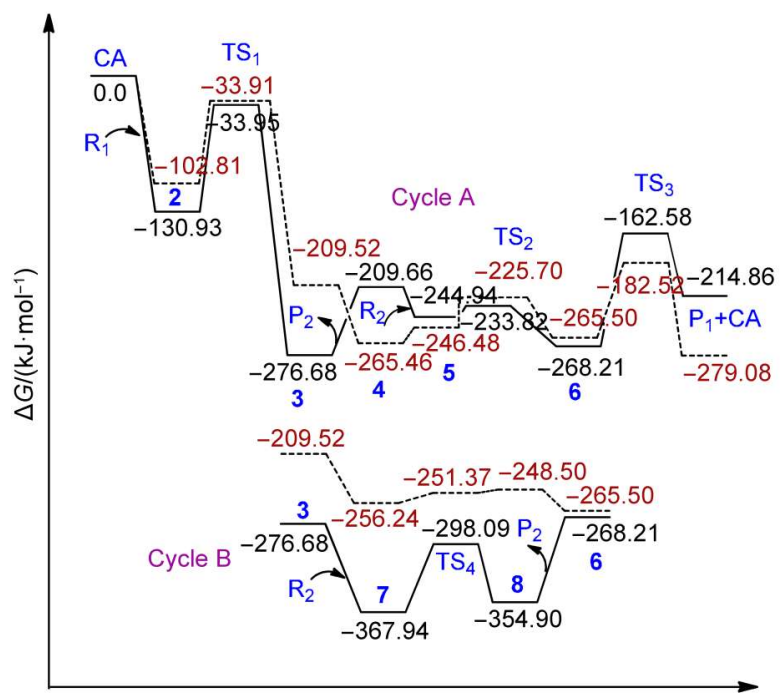

Fig.6 Gibbs free energy in gas phase ( $\Delta G_{\mathrm{g}}$, solid line) and Gibbs free energies in THF solution $\left(\Delta G_{\text {sol }}, 298 \mathrm{~K}\right.$, dashed line) for the overall catalytic cycles 
only $7.74 \mathrm{~kJ} \cdot \mathrm{mol}^{-1}$, which is smaller than that of Cycle A. So the catalytic Cycle B without forming $[\mathrm{Ar}-\mathrm{Fe}(\mathrm{MgBr})]$ is favored over the catalytic Cycle A with forming $[\mathrm{Ar}-\mathrm{Fe}(\mathrm{MgBr})]$ when considering the solvent effect, this conclusion keeps line with our previous study. ${ }^{40}$

For the other steps from 2 to $\mathrm{TS}_{1}$ and $\mathbf{6}$ to $\mathrm{TS}_{3}$, the solvent effect is also large, where the $\Delta G_{\text {sol }}\left(2 \rightarrow \mathrm{TS}_{1}\right)$ in THF is $68.90 \mathrm{~kJ} \cdot \mathrm{mol}^{-1}$ compared to $\Delta G_{\mathrm{g}}\left(\mathbf{2} \rightarrow \mathrm{TS}_{1}\right)$ in the gas phase $\left(96.98 \mathrm{~kJ} \cdot \mathrm{mol}^{-1}\right)$ and the $\Delta G_{\text {sol }}\left(6 \rightarrow \mathrm{TS}_{3}\right)$ in THF is $82.98 \mathrm{~kJ} \cdot \mathrm{mol}^{-1}$ compared to $\Delta G_{\mathrm{g}}(6$ $\left.\rightarrow \mathrm{TS}_{3}\right)$ in the gas phase $\left(105.63 \mathrm{~kJ} \cdot \mathrm{mol}^{-1}\right)$. It can be seen that the solvent effects can lower the energy barrier. These variations can be clearly seen in Fig.6.

In all, the rate-limiting step in the whole catalytic cycles for both Cycle A and Cycle B is the reductive elimination of $\mathbf{6}$ to form $\mathrm{P}_{1}$ when the catalyst CA is re-generated, where the $\Delta G_{\text {sol }}$ is 82.98 $\mathrm{kJ} \cdot \mathrm{mol}^{-1}$ in THF solvent using the CPCM method. The conclusion is the same as our previous study about $\left[\mathrm{Fe}(\mathrm{MgBr})_{2}\right]$ catalyzed cross-coupling reaction between 4-chlorobenzoic acid methyl ester and $n$-hexylicmagnesium bromide. ${ }^{40}$ The CPCM method has been widely used to study the solvent effect for transition metalcatalyzed cross-coupling reactions. ${ }^{59,60}$

\section{Conclusions}

Our studies reported the first theoretical investigation of $\left[\mathrm{Fe}(\mathrm{MgBr})_{2}\right]$ catalyzed cross-coupling reaction between orthochlorostyrene and phenylmagnesium bromide using DFT calculations. We studied two mechanisms. One is named as Cycle A with forming [Ar- $\mathrm{Fe}(\mathrm{MgBr})]$ in the catalytic cycle. It includes three basic steps: (I) oxidation of $\left[\mathrm{Fe}(\mathrm{MgBr})_{2}\right]$ to obtain the intermediate 4, [Ar- $\mathrm{Fe}(\mathrm{MgBr})]$, (II) addition to yield the intermediate 6, $\left[\mathrm{Ar}\right.$-(phenyl)- $\left.\mathrm{Fe}(\mathrm{MgBr})_{2}\right]$ and (III) reductive elimination to return to the catalyst $\mathrm{CA},\left[\mathrm{Fe}(\mathrm{MgBr})_{2}\right]$. Another is named as Cycle B without forming [ $\mathrm{Ar}-\mathrm{Fe}(\mathrm{MgBr})]$ in the catalytic cycle. In the first step, the phenylmagnesium bromide $R_{2}$ attacks the intermediate $\mathbf{3}$ directly to form a new intermediate $\mathbf{7}$ before the molecule $\mathrm{P}_{2}[\mathrm{Cl}-\mathrm{Mg}-\mathrm{Br}]$ dissociates to form the intemediate 4, [Ar$\mathrm{Fe}(\mathrm{MgBr})]$.

The solvent effects can lower the energy barrier. The catalytic Cycle B without forming [ $\mathrm{Ar}-\mathrm{Fe}(\mathrm{MgBr})]$ is favored over the catalytic Cycle A with forming [ $\mathrm{Ar}-\mathrm{Fe}(\mathrm{MgBr})]$ when considering the solvent effect. The rate-limiting step in the whole catalytic cycles for both Cycle A and Cycle B is the reductive elimination of 6 to form $\mathrm{P}_{1}$ when the catalyst $\mathrm{CA}$ is re-generated, where the $\Delta G_{\text {sol }}$ is $82.98 \mathrm{~kJ} \cdot \mathrm{mol}^{-1}$ in THF solvent using the CPCM method.

Supporting Information: Detailed molecule coordinates of all optimized structures and the calculated energy values are included. This information is available free of charge via the internet at http://www.whxb.pku.edu.cn.

\section{References}

(1) Negishi, E. Accounts Chem. Res. 1982, 15, 340. doi: 10.1021/ ar00083a001
(2) Yang, Y.; Oldenhuis, N. J.; Buchwald, S. L. Angew. Chem. Int. Edit. 2013, 125, 643. doi: 10.1002/ange.201207750

(3) Blangetti, M.; Rosso, H.; Prandi, C.; Deagostino, A.; Venturello, P. Molecules 2013, 18, 1188. doi: 10.3390/molecules 18011188

(4) Miyaura, N.; Suzuki, A. J. Chem. Soc. Chem. Commun. 1979, 19, 866. doi: 10.1039/C39790000866

(5) Heck, R. F.; Nolley, J. P. J. Org. Chem. 1972, 37, 2320. doi: 10.1021/jo00979a024

(6) Cabri, W.; Candiani, I. Accounts Chem. Res. 1995, 28, 2. doi: 10.1021/ar00049a001

(7) Milstein, D.; Stille, J. K. J. Am. Chem. Soc. 1978, 100, 3636. doi: 10.1021/ja00479a077

(8) Yabe, Y.; Maegawa, T.; Monguchi, Y.; Sajiki, H. Tetrahedron 2010, 66, 8654. doi: 10.1016/j.tet.2010.09.027

(9) Tamao, K.; Sumitani, K.; Kumada, M. J. Am. Chem. Soc. 1972, 94, 4374. doi: 10.1021/ja00767a075

(10) Yang, L. M.; Huang, L. F.; Luh, T. Y. Org. Lett. 2004, 6, 1461. doi: $10.1021 / 01049686 \mathrm{~g}$

(11) Vechorkin, O.; Proust, V.; Hu, X. J. Am. Chem. Soc. 2009, 131, 9756. doi: 10.1021/ja9027378

(12) Torssell, K. B. Natural Product Chemistry: a Mechanistic and Biosynthetic Approach to Secondary Metabolism; John Wiley \& Sons: New Jersey, 1983; p 401.

(13) Hassan, J.; Sevignon, M.; Gozzi, C.; Schulz, E.; Lemaire, M. Chem. Rev. 2002, 102, 1359. doi: 10.1021/cr000664r

(14) Miyaura, N.; Suzuki, A. Chem. Rev. 1995, 95, 2457. doi: 10.1021/cr00039a007

(15) Bringmann, G.; Mortimer, A. J. P.; Keller, P. A.; Gresser, M. J.; Garner, J.; Breuning, M. Angew. Chem. Int. Edit. 2005, 44, 5384.

(16) Kirsch, P.; Bremer, M. Angew. Chem. Int. Edit. 2000, 39, 4216.

(17) Bauer, E. B. Curr. Org. Chem. 2008, 12, 1341. doi: 10.2174/ 138527208786241556

(18) Bolm, C.; Legros, J.; Paih, J. L.; Zani, L. Chem. Rev. 2004, 104, 6217. doi: $10.1021 / \mathrm{cr} 040664 \mathrm{~h}$

(19) Czaplik, W. M.; Mayer, M.; Cvengros, J.; von Wangelin, A. J. ChemSusChem 2009, 2, 396. doi: 10.1002/cssc.v2:5

(20) Sherry, B. D.; Furstner, A. Accounts Chem. Res. 2008, 41, 1500. doi: $10.1021 / \operatorname{ar} 800039 x$

(21) Furstner, A.; Leitner, A. Angew. Chem. Int. Edit. 2002, 41, 609.

(22) Furstner, A.; Leitner, A.; Mendez, M.; Krause, H. J. Am. Chem. Soc. 2002, 124, 13856. doi: 10.1021/ja027190t

(23) Correa, A.; Mancheno, O. G.; Bolm, C. Chem. Soc. Rev. 2008, 37, 1108. doi: 10.1039/b801794h

(24) Furstner, A.; Martin, R. Chem. Lett. 2005, 34, 624. doi: 10.1246/ cl.2005.624

(25) Furstner, A.; Martin, R.; Krause, H.; Seidel, G.; Goddard, R.; Lehmann, C. W. J. Am. Chem. Soc. 2008, 130, 8773. doi: 10.1021/ja801466t

(26) Noda, D.; Sunada, Y.; Hatakeyama, T.; Nakamura, M.; Nagashima, H. J. Am. Chem. Soc. 2009, 131, 6078. doi: $10.1021 / \mathrm{ja} 901262 \mathrm{~g}$ 
(27) Scheiper, B.; Bonnekessel, M.; Krause, H.; Furstner, A. J. Org. Chem. 2004, 69, 3943. doi: 10.1021/jo0498866

(28) Molander, G. A.; Rahn, B. J.; Shubert, D. C. Tetrahedron Lett. 1983, 24, 5449. doi: 10.1016/S0040-4039(00)94109-1

(29) Quintin, J.; Franck, X.; Hocquemiller, R.; Figadere, B. Tetrahedron Lett. 2002, 43, 3547. doi: 10.1016/S0040-4039(02) 00568-3

(30) Hocek, M.; Dvorakova, H. J. Org. Chem. 2003, 68, 5773. doi: $10.1021 /$ jo034351i

(31) Hatakeyama, T.; Nakamura, M. J. Am. Chem. Soc. 2007, 129, 9844. doi: $10.1021 / \mathrm{ja} 0730841$

(32) Hatakeyama, T.; Hashimoto, S.; Ishizuka, K.; Nakamura, M. J. Am. Chem. Soc. 2009, 131, 11949. doi: 10.1021/ja9039289

(33) Mayer, M.; Welther, A.; von Wangelin, A. J. ChemCatChem 2011, 3, 1567. doi: 10.1002/cctc.v3.10

(34) Clayton, H. S.; Moss, J. R.; Dry, M. E. J. Organomet. Chem. 2003, 688, 181. doi: 10.1016/j.jorganchem.2003.08.044

(35) Knolker, H. J. Chem. Soc. Rev. 1999, 28, 151. doi: 10.1039/ a705401g

(36) Gulak, S.; von Wangelin, A. J. Angew. Chem. Int. Edit. 2012, 51, 1357. doi: 10.1002/anie. 201106110

(37) Smith, R. S.; Kochi, J. K. J. Org. Chem. 1976, 41, 502. doi: 10.1021/jo00865a019

(38) Bogdanovic, B.; Schwickardi, M. Angew. Chem. Int. Edit. 2000, 39,4610 .

(39) Kleimark, J.; Hedstrom A.; Larsson P. F.; Johansson, C.; Norrby, P. ChemCatChem 2009, 1, 152. doi: 10.1002/cctc.v1:1

(40) Ren, Q.; Guan, S.; Jiang, F.; Fang, J. J. Phys. Chem. A 2013, 117, 756. doi: 10.1021/jp3045498

(41) Czaplik, W. M.; Mayer, M.; von Wangelin, A. J. ChemCatChem 2011, 3, 135. doi: 10.1002/cctc.201000276

(42) Mo, Z.; Zhang, Q.; Deng, L. Organometallics 2012, 31, 6518. doi: 10.1021/om $300722 \mathrm{~g}$

(43) Becke, A. D. Phys. Rev. A 1988, 38, 3098. doi: 10.1103/ PhysRevA.38.3098
(44) Becke, A. D. J. Chem. Phys. 1993, 98, 5648. doi: 10.1063/ 1.464913

(45) Hertwig, R. H.; Koch, W. Chem. Phys. Lett. 1997, 268, 345. doi: 10.1016/S0009-2614(97)00207-8

(46) Lee, C. T.; Yang, W. T.; Parr, R. G. Phys. Rev. B 1988, 37, 785. doi: 10.1103/PhysRevB.37.785

(47) Stephens, P. J.; Devlin, F. J.; Chabalowski, C. F.; Frisch, M. J. J Phys. Chem. 1994, 98, 11623. doi: 10.1021/j100096a001

(48) Vosko, S. H.; Wilk, L.; Nusair, M. Can. J. Phys. 1980, 58, 1200. doi: 10.1139/p80-159

(49) Frisch, M. J.; Trucks, G. W.; Schlegel, H. B.; et al. Gaussian 03, Revision C.02; Gaussian Inc.; Wallingford, CT, 2004.

(50) Krishnan, R.; Binkley, J. S.; Seeger, R.; Pople, J. A. J. Chem. Phys. 1980, 72, 650. doi: 10.1063/1.438955

(51) McLean, A. D.; Chandler, G. S. J. Chem. Phys. 1980, 72, 5639. doi: $10.1063 / 1.438980$

(52) Andrae, D.; Haussermann, U.; Dolg, M.; Stoll, H.; Preuss, H. Theor. Chim. Acta. 1990, 77, 123. doi: 10.1007/BF01114537

(53) Cossi, M.; Rega, N.; Scalmani, G.; Barone, V. J. Comput. Chem. 2003, 24, 669. doi: 10.1002/jcc.10189

(54) Castejon, H.; Wiberg, K. B. J. Am. Chem. Soc. 1999, 121, 2139. doi: $10.1021 /$ ja983736t

(55) Perng, B. C.; Newton, M. D.; Raineri, F. O.; Friedman, H. L. J. Chem. Phys. 1996, 104, 7153 and 7177.

(56) Najafi, M.; Zahedi, M.; Klein, E. Comput. Theor. Chem. 2011, 978, 16. doi: 10.1016/j.comptc.2011.09.014

(57) Schubert, G.; Papai, I. J. Am. Chem. Soc. 2003, 125, 14847. doi: $10.1021 / \mathrm{ja} 035791 \mathrm{u}$

(58) Belelli, P. G.; Damiani, D. E.; Castellani, N. J. Chem. Phys. Lett. 2005, 401, 515. doi: 10.1016/j.cplett.2004.11.089

(59) Feng, J.; Ren, Q. H. Acta. Phys. -Chim. Sin. 2014, 30, 821. [蒋 峰, 任清华. 物理化学学报, 2014, 30, 821.]

(60) Nova, A.; Ujaque, G.; Maseras, F.; Liedos, A.; Espinet, P. J. Am. Chem. Soc. 2006, 128, 14571. doi: 10.1021/ja0635736 
Supplementary Information for Acta Phys. -Chim. Sin. 2015, 31 (5), 852-858 doi: 10.3866/PKU.WHXB201503026

\title{
铁催化芳基格氏试剂的联芳交叉偶联的反应机理
}

\author{
任清华*＼cjkstart沈晓燕 \\ (上海大学理学院化学系, 上海 200444)
}

\section{Reaction Mechanism for the Iron-Catalyzed Biaryl Cross-Coupling of Aryl Grignard Reagents}

$$
\text { REN Qing-Hua* } \quad \text { SHEN Xiao-Yan }
$$

(Department of Chemistry, College of Science, Shanghai University, Shanghai 200444, P. R. China)

*Corresponding author. Email: qinghua.ren@shu.edu.cn; Tel: +86-21-66132404; Fax: +86-21-66134594. 
Table S1 The calculated values of electronic energy $\Delta E$, zero-point energy correction $\triangle \mathrm{ZPE}$, relative enthalpy $\Delta H$, relative entropy $\Delta S$, Gibbs free energy $\Delta G_{\mathrm{g}}$ and Gibbs free energy in solution THF, $\Delta G_{\text {sol }},(298 \mathrm{~K})$ for the overall catalytic cycles

\begin{tabular}{|c|c|c|c|c|c|c|}
\hline & $\triangle E$ & $\triangle \mathrm{ZPE}$ & $\triangle H$ & $\triangle S$ & $\triangle G_{\mathrm{g}}$ & $\triangle G_{\mathrm{sol}}$ \\
\hline $\mathrm{CA}+\mathrm{R}_{1}$ & 0.0 & 0.0 & 0.0 & 0.0 & 0.0 & 0.0 \\
\hline 2 & -194.86 & 3.89 & -191.29 & -202.44 & -130.93 & -102.81 \\
\hline $\mathrm{TS}_{1}$ & -88.75 & -1.93 & -90.29 & -188.96 & -33.95 & -33.91 \\
\hline 3 & -334.50 & 2.21 & -330.98 & -182.14 & -276.68 & -209.52 \\
\hline $4+\mathrm{P}_{2}$ & -219.34 & -2.25 & -220.91 & -37.75 & -209.66 & -265.46 \\
\hline 5 & -304.52 & 0.39 & -300.85 & -187.53 & -244.94 & -246.48 \\
\hline $\mathrm{TS}_{2}$ & -299.65 & -0.16 & -298.78 & -217.91 & -233.82 & -225.70 \\
\hline 6 & -327.85 & -0.06 & -324.56 & -188.99 & -268.21 & -265.50 \\
\hline $\mathrm{TS}_{3}$ & -231.38 & -1.66 & -232.66 & -235.05 & -162.58 & -182.52 \\
\hline$P_{1}$ & -228.50 & 5.07 & -223.43 & -28.76 & -214.86 & -279.08 \\
\hline 7 & -478.91 & 4. 40 & -470.71 & -344.70 & -367.94 & -256.24 \\
\hline $\mathrm{TS}_{4}$ & -423.70 & 5.37 & -417.37 & -400.05 & -298.09 & -251.37 \\
\hline 8 & -466.42 & 4. 34 & -458.52 & -347.54 & -354.90 & -248.50 \\
\hline
\end{tabular}

The unit of relative entropy $\Delta S$ is $\mathrm{J} \cdot \mathrm{mol}^{-1} \cdot \mathrm{K}^{-1}$ and all other energy units are $\mathrm{kJ} \cdot \mathrm{mol}^{-1}$.

\section{The full optimized geometries:}

5

Molecule CA

$\begin{array}{lrrr}\mathrm{Fe} & 0.00000000 & 0.00000000 & 2.39143900 \\ \mathrm{Mg} & 0.00000000 & 1.80703100 & 0.64199400 \\ \mathrm{Mg} & 0.00000000 & -1.80703100 & 0.64199400 \\ \mathrm{Br} & 0.00000000 & -3.42084500 & -1.10836100 \\ \mathrm{Br} & 0.00000000 & 3.42084500 & -1.10836100\end{array}$


16

Molecule R1

$\begin{array}{lrrr}\text { C } & -2.43269000 & -0.39722900 & 0.06258200 \\ \text { C } & -1.68006100 & 0.77226000 & 0.06810700 \\ \text { C } & -0.29244700 & 0.69870800 & -0.01148100 \\ \text { C } & 0.38882900 & -0.52752200 & -0.09408900 \\ \text { C } & -0.40606900 & -1.68779300 & -0.10913700 \\ \text { C } & -1.79061000 & -1.63199800 & -0.02673500 \\ \text { H } & -3.51338500 & -0.34030500 & 0.12070700 \\ \text { H } & -2.15931300 & 1.74045100 & 0.13605100 \\ \text { H } & 0.08404600 & -2.64860800 & -0.21165300 \\ \text { Cl } & 0.60142500 & 2.21999400 & 0.01874800 \\ \text { C } & 1.85691900 & -0.60188900 & -0.17813600 \\ \text { H } & 2.35150500 & 0.27713600 & -0.57704500 \\ \text { C } & 2.60777000 & -1.63761500 & 0.20677600 \\ \text { H } & 2.18751900 & -2.52972700 & 0.65824400 \\ \text { H } & 3.68495300 & -1.61229600 & 0.09406200 \\ \text { H } & -2.36941200 & -2.54808600 & -0.04640200\end{array}$

21

Molecule 2

$\begin{array}{lrrr}\mathrm{Fe} & -0.22599900 & -0.80855000 & -0.04218800 \\ \mathrm{Mg} & 2.19780300 & -0.13650200 & -0.20441100 \\ \mathrm{Mg} & -0.42584500 & 1.69799200 & -0.27804900 \\ \mathrm{Br} & -1.15323900 & 3.96895000 & -0.21581700 \\ \mathrm{Br} & 4.58083200 & -0.14123000 & -0.08717100 \\ \mathrm{Cl} & -2.23562900 & -3.01635200 & -1.70262500 \\ \mathrm{C} & -1.58389600 & -2.36833800 & -0.19657800 \\ \mathrm{C} & -2.27011100 & -1.31459100 & 0.47977500 \\ \mathrm{C} & -0.34587000 & -2.90845900 & 0.23469300 \\ \mathrm{C} & -1.57469700 & -0.76202500 & 1.59458000 \\ \mathrm{C} & 0.29510000 & -2.35537000 & 1.35988200 \\ \mathrm{H} & 0.10898700 & -3.70896600 & -0.33285800 \\ \mathrm{C} & -0.32944400 & -1.27168900 & 2.02494500 \\ \mathrm{H} & -2.00914800 & 0.07869300 & 2.12046900 \\ \mathrm{H} & 1.23650200 & -2.75768900 & 1.71094400 \\ \mathrm{C} & -3.59384400 & -0.82662200 & 0.06639400 \\ \mathrm{H} & -3.85455600 & -0.98345600 & -0.97394200 \\ \mathrm{C} & -4.47861700 & -0.23932600 & 0.87695000 \\ \mathrm{H} & -4.29814500 & -0.09511100 & 1.93648000 \\ \mathrm{H} & -5.43002100 & 0.11030000 & 0.49559000 \\ \mathrm{H} & 0.18706100 & -0.77303200 & 2.83508500 \\ 2 \mathrm{I} & & & \end{array}$

21

Molecule TS1 


$\begin{array}{lrrr}\mathrm{Fe} & -0.44150300 & -0.52235500 & -0.00618500 \\ \mathrm{Mg} & 2.07663700 & -1.12766400 & -0.19803600 \\ \mathrm{Mg} & 0.73392700 & 1.67571900 & -0.12513400 \\ \mathrm{Br} & 1.19725000 & 4.00018200 & -0.00803700 \\ \mathrm{Br} & 4.18034600 & -2.23498000 & -0.29193400 \\ \mathrm{Cl} & -1.34540500 & -1.62822600 & 1.90529800 \\ \mathrm{C} & -2.24171100 & -0.53853500 & 0.42565200 \\ \mathrm{C} & -3.31194200 & -1.10071800 & -0.33115000 \\ \mathrm{C} & -2.10019000 & 0.86281800 & 0.66724000 \\ \mathrm{C} & -4.10721100 & -0.17567000 & -1.00086600 \\ \mathrm{C} & -3.00225100 & 1.73716200 & 0.00084100 \\ \mathrm{H} & -1.61783300 & 1.21939500 & 1.56907500 \\ \mathrm{C} & -3.96099000 & 1.21957900 & -0.84168600 \\ \mathrm{H} & -4.85583900 & -0.54401700 & -1.69328000 \\ \mathrm{H} & -2.95717200 & 2.80178800 & 0.20253400 \\ \mathrm{C} & -3.48201200 & -2.55490700 & -0.45148700 \\ \mathrm{H} & -2.63345400 & -3.15447900 & -0.13901400 \\ \mathrm{C} & -4.58873900 & -3.18123300 & -0.86299200 \\ \mathrm{H} & -5.49313000 & -2.65132000 & -1.14097200 \\ \mathrm{H} & -4.62358800 & -4.26221800 & -0.91936100 \\ \mathrm{H} & -4.64038600 & 1.88221000 & -1.36451100 \\ 2 & & & \end{array}$

21

Molecule 3

$\mathrm{Fe}$

0. 25998700

$-1.49542400$

$-0.31805900$

$\mathrm{Mg}$

$-2.23390100$

$-0.80140800$

$-0.08035500$

$\mathrm{Mg}$

0. 30721800

1. 02905000

$-0.20092800$

0. 38831400

3. 36750500

$-0.55627900$

$-4.38492200$

0. 08705800

0. 33448800

$\mathrm{Cl}$

$-1.35728400$

$-3.04247500$

$-0.33022900$

C

1. 83167300

$-0.57383300$

0. 50757400

1. 78700500

$-0.20780900$

1. 87351700

3. 11475800

$-0.69446900$

$-0.10560000$

2. 94439300

0. 01678900

2. 61746900

0. 82806800

-0. 12421900

2. 38016400

4. 26688600

$-0.42938100$

0. 64690100

4. 18522500

$-0.08706800$

1. 99333100

2. 87650300

0. 28316900

3. 66596900

5. 24020100

$-0.47570800$

0. 17176800

3. 20399100

$-1.09606200$

$-1.52245700$

2. 28855000

$-0.96130400$

$-2.09953300$

4. 26198700

$-1.62288800$

$-2.14630100$

5. 20102000

$-1.81708400$

$-1.64014900$

H

4. 21326900

$-1.88849900$

-3. 19522500 


$\begin{array}{lrrr}\text { H } & 5.09250300 & 0.11364500 & 2.55191300 \\ \text { I8 } & & & \\ \text { Molecule } 4 & & \\ \text { Fe } & 0.87212000 & 2.18614400 & -0.28289300 \\ \text { Mg } & -1.11905800 & 0.77019000 & -0.09162300 \\ \mathrm{Br} & -3.08482300 & -0.56116400 & 0.08174900 \\ \mathrm{C} & 1.33816000 & -0.17504000 & -1.81541700 \\ \mathrm{C} & 1.80121500 & -1.46102700 & -2.08268100 \\ \mathrm{H} & 0.98992100 & 0.43219400 & -2.64840400 \\ \mathrm{C} & 2.24818900 & -1.76835100 & 0.26775600 \\ \mathrm{C} & 2.25979800 & -2.25849600 & -1.03365600 \\ \mathrm{H} & 1.80991100 & -1.83729600 & -3.09984600 \\ \mathrm{H} & 2.63060600 & -2.38896800 & 1.07067800 \\ \mathrm{C} & 1.75758700 & 0.03421600 & 1.93959000 \\ \mathrm{H} & 1.74171500 & 1.12035500 & 2.03471000 \\ \mathrm{C} & 1.73764400 & -0.68250900 & 3.06836300 \\ \mathrm{H} & 1.72307400 & -1.76690100 & 3.06746200 \\ \mathrm{H} & 1.72497600 & -0.19771900 & 4.03706100 \\ \mathrm{H} & 2.63107800 & -3.25780000 & -1.23068200 \\ \mathrm{C} & 1.77927300 & -0.47734100 & 0.55513900 \\ \mathrm{C} & 1.32331700 & 0.36436000 & -0.50534500\end{array}$

3

Molecule P2

$\begin{array}{lrrr}\mathrm{Mg} & 0.00000000 & 0.00000000 & -0.69375300 \\ \mathrm{Cl} & 0.00000000 & 0.00000000 & -2.88562500 \\ \mathrm{Br} & 0.00000000 & 0.00000000 & 1.63944700\end{array}$

13

Molecule R2

$\begin{array}{lrrr}\mathrm{Mg} & 0.72792400 & -0.00028900 & -0.00001100 \\ \mathrm{Br} & 3.08433800 & 0.00005500 & -0.00003400 \\ \mathrm{C} & -1.35077400 & -0.00029800 & 0.00024700 \\ \mathrm{C} & -2.09211900 & -1.19845500 & 0.00014900 \\ \mathrm{C} & -2.09158500 & 1.19818900 & 0.00015000 \\ \mathrm{C} & -3.48792200 & -1.20387900 & -0.00006300 \\ \mathrm{H} & -1.58387500 & -2.16001500 & 0.00027800 \\ \mathrm{C} & -3.48739900 & 1.20424100 & -0.00006300 \\ \mathrm{H} & -1.58294200 & 2.15954300 & 0.00027800 \\ \mathrm{C} & -4.18928000 & 0.00034000 & -0.00018800 \\ \mathrm{H} & -4.02636300 & -2.14607200 & -0.00012900 \\ \mathrm{H} & -4.02541000 & 2.14668000 & -0.00013000 \\ \mathrm{H} & -5.27386200 & 0.00057000 & -0.00037600\end{array}$

31

Molecule 5 


\begin{tabular}{lrrr} 
C & 4.40816600 & 1.21746500 & -0.99558200 \\
$\mathrm{C}$ & 3.13503000 & 0.74273800 & -1.30572200 \\
$\mathrm{C}$ & 1.97909600 & 1.19812000 & -0.62663100 \\
$\mathrm{C}$ & 2.15378500 & 2.17830100 & 0.39850100 \\
$\mathrm{C}$ & 3.44502700 & 2.62854400 & 0.70969900 \\
$\mathrm{C}$ & 4.55886300 & 2.15964800 & 0.01955100 \\
$\mathrm{H}$ & 5.27255900 & 0.84080000 & -1.53011400 \\
$\mathrm{H}$ & 3.04237900 & -0.00637900 & -2.08739000 \\
$\mathrm{H}$ & 3.57787300 & 3.34438700 & 1.51314500 \\
$\mathrm{Mg}$ & 1.26101100 & -0.92217300 & 0.12396000 \\
$\mathrm{Br}$ & 2.42524900 & -2.90023400 & -0.54538300 \\
$\mathrm{Fe}$ & 0.28425300 & 0.96559800 & -1.48898000 \\
$\mathrm{Mg}$ & -1.77911800 & -0.17912900 & -0.02878200 \\
$\mathrm{Br}$ & -0.46344800 & -1.05916400 & 2.00421800 \\
$\mathrm{C}$ & -3.84587400 & 0.03784300 & -0.33285700 \\
$\mathrm{C}$ & -4.77314200 & -0.27080100 & 0.68216400 \\
$\mathrm{C}$ & -4.38456200 & 0.50385200 & -1.54823700 \\
$\mathrm{C}$ & -6.14997900 & -0.12564100 & 0.49959000 \\
$\mathrm{H}$ & -4.42632500 & -0.63817200 & 1.64564600 \\
$\mathrm{C}$ & -5.75887900 & 0.65353500 & -1.74493100 \\
$\mathrm{H}$ & -3.72607700 & 0.75840600 & -2.37688000 \\
$\mathrm{C}$ & -6.64648800 & 0.33823600 & -0.71755700 \\
$\mathrm{H}$ & -6.83391100 & -0.37534700 & 1.30474300 \\
$\mathrm{H}$ & -6.13654900 & 1.01369900 & -2.69687900 \\
$\mathrm{H}$ & -7.71526500 & 0.45180800 & -0.86444000 \\
$\mathrm{C}$ & 0.97673900 & 2.73432200 & 1.09434600 \\
$\mathrm{H}$ & 0.11891600 & 2.06994000 & 1.17235200 \\
$\mathrm{C}$ & 0.87035100 & 3.96108500 & 1.61445800 \\
$\mathrm{H}$ & -0.03689400 & 4.27745200 & 2.11493100 \\
$\mathrm{H}$ & 1.67164000 & 4.68929900 & 1.55120800 \\
$\mathrm{H}$ & 5.54651200 & 2.51963500 & 0.28503400 \\
$3 \mathrm{H}$ & & & \\
\hline & & &
\end{tabular}

31

Molecule TS2

$\begin{array}{lrrr}\mathrm{C} & 3.53020400 & 2.27829400 & -1.42446400 \\ \mathrm{C} & 2.34050500 & 1.56280700 & -1.52817900 \\ \mathrm{C} & 1.37890100 & 1.55650000 & -0.49049800 \\ \mathrm{C} & 1.66789200 & 2.31321000 & 0.68663100 \\ \mathrm{C} & 2.88274800 & 3.00851400 & 0.78382200 \\ \mathrm{C} & 3.80112400 & 2.99711700 & -0.26018600 \\ \mathrm{H} & 4.24903200 & 2.25764600 & -2.23557700 \\ \mathrm{H} & 2.16132700 & 0.98797100 & -2.43284600 \\ \mathrm{H} & 3.11623400 & 3.55288800 & 1.69210200 \\ \mathrm{Mg} & 1.28952800 & -0.81616600 & -0.07580900\end{array}$




$\begin{array}{lrrr}\mathrm{Br} & 2.99824500 & -2.19773000 & -1.02326100 \\ \mathrm{Fe} & -0.41479700 & 1.02448500 & -0.85435400 \\ \mathrm{Mg} & -1.72064900 & -0.96016600 & 0.37065500 \\ \mathrm{Br} & -0.05043500 & -2.07846000 & 1.86095100 \\ \mathrm{C} & -3.63044900 & -0.30317300 & -0.22359300 \\ \mathrm{C} & -4.59279600 & 0.21869600 & 0.66508600 \\ \mathrm{C} & -3.98161300 & -0.31139900 & -1.58945600 \\ \mathrm{C} & -5.82943900 & 0.69127900 & 0.22434900 \\ \mathrm{H} & -4.38838000 & 0.25622200 & 1.73286800 \\ \mathrm{C} & -5.21614500 & 0.15948900 & -2.04345500 \\ \mathrm{H} & -3.28726600 & -0.70365500 & -2.33070400 \\ \mathrm{C} & -6.14389500 & 0.66288600 & -1.13436100 \\ \mathrm{H} & -6.54843800 & 1.07976500 & 0.93872400 \\ \mathrm{H} & -5.45299500 & 0.13167400 & -3.10233600 \\ \mathrm{H} & -7.10422300 & 1.02978300 & -1.48018700 \\ \mathrm{C} & 0.66425700 & 2.37496900 & 1.76569600 \\ \mathrm{H} & -0.04935500 & 1.54976700 & 1.78235300 \\ \mathrm{C} & 0.53165400 & 3.32565900 & 2.69630600 \\ \mathrm{H} & -0.24604300 & 3.26523100 & 3.44793700 \\ \mathrm{H} & 1.18082700 & 4.19334300 & 2.73739700 \\ \mathrm{H} & 4.73640000 & 3.53628800 & -0.16000800 \\ \mathrm{H} & & & \end{array}$

31

Molecule 6

$\begin{array}{lrrr}\text { C } & -1.92562100 & 2.68568000 & -2.29598400 \\ \text { C } & -1.40000800 & 1.44302000 & -1.95285000 \\ \text { C } & -1.22477100 & 1.05359800 & -0.60557100 \\ \text { C } & -1.55761600 & 2.01229500 & 0.39267500 \\ \text { C } & -2.06660300 & 3.27200500 & 0.03675500 \\ \text { C } & -2.26068200 & 3.60416000 & -1.29845400 \\ \text { H } & -2.06480900 & 2.94398100 & -3.34013900 \\ \text { H } & -1.12113400 & 0.75999900 & -2.75287400 \\ \text { H } & -2.32998500 & 3.97815800 & 0.81661400 \\ \mathrm{Mg} & 0.93037600 & 1.29924300 & 0.15902600 \\ \mathrm{Br} & 2.58286100 & 3.01118800 & 0.26897100 \\ \mathrm{Fe} & -0.68959000 & -0.78345900 & -0.25551300 \\ \mathrm{Mg} & 1.95627400 & -1.53249800 & -0.18091100 \\ \mathrm{Br} & 3.59744200 & -3.25220600 & -0.27115700 \\ \mathrm{C} & -2.43002300 & -1.47435200 & 0.02188100 \\ \mathrm{C} & -3.52992600 & -1.50869700 & -0.85242300 \\ \mathrm{C} & -2.48215100 & -2.26715500 & 1.18225400 \\ \mathrm{C} & -4.62554200 & -2.32709500 & -0.58702300 \\ \mathrm{H} & -3.53590000 & -0.88941800 & -1.74474700 \\ \mathrm{C} & -3.57802800 & -3.09267100 & 1.45139500\end{array}$




\begin{tabular}{|c|c|c|c|}
\hline $\mathrm{H}$ & -1.65788500 & -2.25300900 & 1. 89835800 \\
\hline $\mathrm{C}$ & -4.65024100 & -3.12102300 & 0.56329100 \\
\hline $\mathrm{H}$ & -5.46606300 & -2.34697600 & -1.27308700 \\
\hline $\mathrm{H}$ & -3.59599100 & -3.70145700 & 2. 34916500 \\
\hline $\mathrm{H}$ & -5.50701900 & -3.75354900 & 0.76732700 \\
\hline $\mathrm{C}$ & -1.31653200 & 1. 64852400 & 1. 81220500 \\
\hline $\mathrm{H}$ & -1.65578700 & 0.65771200 & 2. 10987100 \\
\hline $\mathrm{C}$ & -0.70613500 & 2. 42622100 & 2. 71681100 \\
\hline $\mathrm{H}$ & -0.33848500 & 3. 41649800 & 2. 46780300 \\
\hline $\mathrm{H}$ & -0.56017900 & 2. 09137500 & 3. 73738600 \\
\hline $\mathrm{H}$ & -2.66455300 & 4. 57427900 & -1.56300200 \\
\hline \multicolumn{4}{|l|}{34} \\
\hline \multicolumn{4}{|c|}{ Molecule 7} \\
\hline $\mathrm{C}$ & -2.85401600 & -3.68829300 & -1.81723800 \\
\hline $\mathrm{C}$ & -2.03799900 & -2.56694200 & -1.67938200 \\
\hline $\mathrm{C}$ & -1.92656400 & -1.85797300 & -0.46166300 \\
\hline $\mathrm{C}$ & -2.73518700 & -2.30872400 & 0.61825000 \\
\hline $\mathrm{C}$ & -3.56870300 & -3.42643200 & 0.47131100 \\
\hline $\mathrm{C}$ & -3.61995900 & -4.11888000 & -0.73512800 \\
\hline $\mathrm{H}$ & -2.89742400 & -4.21812600 & -2.76227400 \\
\hline $\mathrm{H}$ & -1.46679000 & -2.24540300 & -2.55187700 \\
\hline $\mathrm{H}$ & -4.16177800 & -3.76344300 & 1. 31434400 \\
\hline $\mathrm{Mg}$ & -2.77859000 & 0.25750200 & -0.02701800 \\
\hline $\mathrm{Br}$ & -4.80762800 & 1. 48019200 & -0.31973300 \\
\hline $\mathrm{Mg}$ & 2. 93539300 & -0.37644700 & -0.06178300 \\
\hline $\mathrm{Br}$ & 0.92540500 & -0.92896200 & 1. 37015800 \\
\hline $\mathrm{Fe}$ & -0.44907000 & -0.59102000 & -0.69346400 \\
\hline $\mathrm{Cl}$ & 1. 42066600 & 0.47721700 & -1.78136700 \\
\hline $\mathrm{Mg}$ & -0.24670200 & 1. 94810700 & -0.35060600 \\
\hline $\mathrm{Br}$ & 0.60971800 & 4. 05514200 & 0.32016200 \\
\hline $\mathrm{C}$ & 4. 99693800 & -0.64077800 & -0.05630400 \\
\hline $\mathrm{C}$ & 5. 66151600 & -1.27252400 & 1.01336200 \\
\hline $\mathrm{C}$ & 5. 80348500 & -0.20185100 & -1.12485000 \\
\hline $\mathrm{C}$ & 7. 04529000 & -1.45668800 & 1. 02043000 \\
\hline $\mathrm{H}$ & 5. 09861900 & -1.63499800 & 1. 87071400 \\
\hline $\mathrm{C}$ & 7. 18812300 & -0.37971600 & -1.12903600 \\
\hline $\mathrm{H}$ & 5.35467500 & 0.29534100 & -1.98189800 \\
\hline $\mathrm{C}$ & 7. 81252200 & -1.00933000 & -0.05375800 \\
\hline $\mathrm{H}$ & 7. 52368700 & -1.94714100 & 1. 86220200 \\
\hline $\mathrm{H}$ & 7. 77829400 & -0.02682500 & -1.96874200 \\
\hline $\mathrm{H}$ & 8. 88818700 & -1.14918000 & -0.05242500 \\
\hline $\mathrm{C}$ & -2.71226900 & -1.54520200 & 1. 89616200 \\
\hline $\mathrm{H}$ & -1.73232700 & -1.35852100 & 2. 32711800 \\
\hline
\end{tabular}




\begin{tabular}{|c|c|c|c|}
\hline $\mathrm{C}$ & -3.79859400 & -1.05729200 & 2. 51129700 \\
\hline $\mathrm{H}$ & -3.71584300 & -0.50022600 & 3. 43775500 \\
\hline $\mathrm{H}$ & -4.79767300 & -1.19720500 & 2. 11150000 \\
\hline $\mathrm{H}$ & -4.25814400 & -4.98969500 & -0.83150200 \\
\hline \multicolumn{4}{|l|}{34} \\
\hline \multicolumn{4}{|c|}{ Molecule TS4 } \\
\hline $\mathrm{C}$ & -3.14165600 & 2. 76441600 & -0.31393100 \\
\hline $\mathrm{C}$ & -2.38942800 & 1. 62179400 & -0.56505100 \\
\hline $\mathrm{C}$ & -1.34290800 & 1. 19043200 & 0.28482900 \\
\hline $\mathrm{C}$ & -1.06230700 & 2. 02676200 & 1. 40576900 \\
\hline $\mathrm{C}$ & -1.83551500 & 3. 17447300 & 1. 66116900 \\
\hline $\mathrm{C}$ & -2.87113400 & 3. 54086500 & 0.81340900 \\
\hline $\mathrm{H}$ & -3.94143500 & 3. 04491700 & -0.99074100 \\
\hline $\mathrm{H}$ & -2.64306900 & 1. 03205500 & -1.44274100 \\
\hline $\mathrm{H}$ & -1.61928400 & 3. 77092300 & 2. 54057900 \\
\hline $\mathrm{Mg}$ & 0.83488300 & 1. 78955800 & -0.34998100 \\
\hline $\mathrm{Br}$ & 1. 75136600 & 3. 85690700 & -1.13035100 \\
\hline $\mathrm{Mg}$ & -1.00604600 & -3.02982800 & 0.08056900 \\
\hline $\mathrm{Br}$ & 0.38699600 & -2.00415100 & 1. 84035900 \\
\hline $\mathrm{Fe}$ & -0.49462100 & -0.47398900 & -0.35270100 \\
\hline $\mathrm{Cl}$ & 0.43402500 & -2.47712100 & -1.71734100 \\
\hline $\mathrm{Mg}$ & 2. 08481800 & -0.97156400 & -0.41792100 \\
\hline $\mathrm{Br}$ & 4. 37315600 & -1.61187800 & -0.27607100 \\
\hline $\mathrm{C}$ & -2.68230400 & -1.84053500 & -0.35907100 \\
\hline $\mathrm{C}$ & -3.58891300 & -1.46194400 & 0.65708900 \\
\hline $\mathrm{C}$ & -3.17685400 & -1.81929400 & -1.68378100 \\
\hline $\mathrm{C}$ & -4.89372300 & -1.06744100 & 0.37298900 \\
\hline $\mathrm{H}$ & -3.26282300 & -1.45052400 & 1. 69371900 \\
\hline $\mathrm{C}$ & -4.48065300 & -1.42154200 & -1.98076100 \\
\hline $\mathrm{H}$ & -2.52774400 & -2.10743600 & -2.50745100 \\
\hline $\mathrm{C}$ & -5.33988200 & -1.04424000 & -0.94927100 \\
\hline $\mathrm{H}$ & -5.56108200 & -0.77110000 & 1. 17525900 \\
\hline $\mathrm{H}$ & -4.82624300 & -1.40648100 & -3.00914100 \\
\hline $\mathrm{H}$ & -6.35427200 & -0.73297900 & -1.17435100 \\
\hline $\mathrm{C}$ & 0.09810300 & 1.72190000 & 2. 28173900 \\
\hline $\mathrm{H}$ & 0.21774100 & 0.68660900 & 2. 58351900 \\
\hline $\mathrm{C}$ & 1.00712400 & 2. 62309800 & 2. 68065900 \\
\hline $\mathrm{H}$ & 1.83608400 & 2. 33684600 & 3. 31803900 \\
\hline $\mathrm{H}$ & 0.95675600 & 3. 66444800 & 2. 37923900 \\
\hline $\mathrm{H}$ & -3.45960200 & 4. 42635600 & 1. 02457900 \\
\hline
\end{tabular}

34

Molecule 8

C

$-1.77290400 \quad-3.89697200 \quad-1.12412200$ 


$\begin{array}{lrrr}\mathrm{C} & -1.31713700 & -2.58437800 & -1.24130200 \\ \mathrm{C} & -0.91342600 & -1.82605300 & -0.11956600 \\ \mathrm{C} & -1.00616400 & -2.45874700 & 1.15583000 \\ \mathrm{C} & -1.48119100 & -3.77471000 & 1.26417000 \\ \mathrm{C} & -1.85642400 & -4.49234600 & 0.13445200 \\ \mathrm{H} & -2.07559100 & -4.44688700 & -2.00831400 \\ \mathrm{H} & -1.25863000 & -2.14658500 & -2.23601100 \\ \mathrm{H} & -1.57577900 & -4.23285900 & 2.24270100 \\ \mathrm{Mg} & -2.67959400 & -0.36986900 & -0.15967800 \\ \mathrm{Br} & -5.02994100 & -0.73270000 & -0.18935400 \\ \mathrm{Mg} & 3.07262800 & 0.59928700 & -0.07151900 \\ \mathrm{Br} & 5.28483500 & 1.06242500 & 0.59096600 \\ \mathrm{Fe} & -0.01209500 & -0.07520200 & -0.19731900 \\ \mathrm{Cl} & 1.22077700 & 2.09377300 & -0.11750100 \\ \mathrm{Mg} & -1.37804500 & 2.31728300 & -0.08555300 \\ \mathrm{Br} & -2.06445000 & 4.59060500 & -0.03818200 \\ \mathrm{C} & 1.67735100 & -1.08486100 & -0.59878100 \\ \mathrm{C} & 2.35740200 & -2.03333400 & 0.20609700 \\ \mathrm{C} & 2.19964500 & -0.91653500 & -1.91382700 \\ \mathrm{C} & 3.42941500 & -2.78950400 & -0.27583400 \\ \mathrm{H} & 2.01843500 & -2.20607500 & 1.22287600 \\ \mathrm{C} & 3.26277000 & -1.68506400 & -2.40739200 \\ \mathrm{H} & 1.73497800 & -0.19781000 & -2.58941600 \\ \mathrm{C} & 3.87902100 & -2.62511800 & -1.58557600 \\ \mathrm{H} & 3.91731300 & -3.50586200 & 0.37608300 \\ \mathrm{H} & 3.60919300 & -1.53903800 & -3.42481100 \\ \mathrm{H} & 4.71126400 & -3.21180900 & -1.95575400 \\ \mathrm{C} & -0.56154300 & -1.69195300 & 2.33331400 \\ \mathrm{H} & -0.55828900 & -0.60310700 & 2.19939000 \\ \mathrm{C} & -0.16203800 & -2.15886100 & 3.52099300 \\ \mathrm{H} & 0.13626400 & -1.48590800 & 4.31565500 \\ \mathrm{H} & -0.12024900 & -3.22028200 & 3.74037700 \\ \mathrm{H} & & -5.50399700 & 0.23525300 \\ 3 \mathrm{I} & & \\ \mathrm{H} & -23170500 & & \\ \mathrm{H} & & \end{array}$

31

Molecule TS3

$\begin{array}{lrrr}\mathrm{C} & -2.71171500 & 1.19240000 & -2.44366000 \\ \mathrm{C} & -1.91933400 & 0.16530800 & -1.96912700 \\ \mathrm{C} & -1.73024000 & -0.08151700 & -0.56999600 \\ \mathrm{C} & -2.41629700 & 0.80822400 & 0.33360900 \\ \mathrm{C} & -3.23998400 & 1.82536300 & -0.18238700 \\ \mathrm{C} & -3.39438700 & 2.02539800 & -1.54585000 \\ \mathrm{H} & -2.80860400 & 1.34770100 & -3.51248400 \\ \mathrm{H} & -1.41717100 & -0.48343800 & -2.68414300\end{array}$




\begin{tabular}{|c|c|c|c|}
\hline $\mathrm{H}$ & -3.76699500 & 2. 46484900 & 0.51650100 \\
\hline Mg & 0.26123000 & 1. 31309300 & 0.10709200 \\
\hline $\mathrm{Br}$ & 0.65078300 & 3. 65670600 & 0.32521300 \\
\hline $\mathrm{Fe}$ & -0.01122900 & -1.08833700 & -0.34097200 \\
\hline Mg & 2. 58255500 & -0.76109600 & -0.22044300 \\
\hline $\mathrm{Br}$ & 4. 94443500 & -1.13057600 & -0.16874700 \\
\hline $\mathrm{C}$ & -1.79050200 & -1.82898700 & -0.19721600 \\
\hline $\mathrm{C}$ & -2.82221200 & -2.54739000 & -0.82600400 \\
\hline $\mathrm{C}$ & -1.23435200 & -2.34191100 & 0.98561100 \\
\hline $\mathrm{C}$ & -3.26500900 & -3.73848200 & -0.26272500 \\
\hline $\mathrm{H}$ & -3.27773000 & -2.16764200 & -1.73349900 \\
\hline $\mathrm{C}$ & -1.66155000 & -3.54656400 & 1. 54366700 \\
\hline $\mathrm{H}$ & -0.41564900 & -1.78086700 & 1. 49329500 \\
\hline $\mathrm{C}$ & -2.69572200 & -4.23762600 & 0.91689200 \\
\hline $\mathrm{H}$ & -4.06005900 & -4.29359200 & -0.74838300 \\
\hline $\mathrm{H}$ & -1.19934800 & -3.93623900 & 2. 44359700 \\
\hline $\mathrm{H}$ & -3.05663600 & -5.16819200 & 1. 33889300 \\
\hline $\mathrm{C}$ & -2.23268100 & 0.68250900 & 1. 79300100 \\
\hline $\mathrm{H}$ & -2.18598100 & -0.32858100 & 2. 18775600 \\
\hline $\mathrm{C}$ & -2.11003300 & 1. 70795800 & 2. 64646400 \\
\hline $\mathrm{H}$ & -2.09999600 & 2. 74047800 & 2. 31446100 \\
\hline $\mathrm{H}$ & -2.00156500 & 1. 53502800 & 3. 71090300 \\
\hline $\mathrm{H}$ & -4.03227100 & 2. 82066000 & -1.91137000 \\
\hline \multicolumn{4}{|c|}{ Molecule P1 } \\
\hline $\mathrm{C}$ & -2.89976200 & 0.59634600 & 0.07172700 \\
\hline $\mathrm{C}$ & -1.50692700 & 0.77544400 & -0.00588300 \\
\hline $\mathrm{C}$ & -0.68383300 & -0.37730400 & 0.02089200 \\
\hline $\mathrm{C}$ & -1.28842800 & -1.64006000 & 0.07096900 \\
\hline $\mathrm{C}$ & -2.67110300 & -1.79354700 & 0.11845900 \\
\hline $\mathrm{C}$ & -3.48321200 & -0.66320200 & 0.12850200 \\
\hline $\mathrm{H}$ & -3.53452500 & 1. 47650000 & 0.06526800 \\
\hline H & -0.65092100 & -2.51693500 & 0.09871700 \\
\hline $\mathrm{H}$ & -3.10539200 & -2.78585800 & 0.16366500 \\
\hline $\mathrm{C}$ & 0.80907000 & -0.33375600 & 0.04496900 \\
\hline $\mathrm{C}$ & 1. 55405700 & -0.90172000 & -0.99558800 \\
\hline $\mathrm{C}$ & 1. 49428500 & 0.21561600 & 1. 13680600 \\
\hline $\mathrm{C}$ & 2. 94818100 & -0.90745900 & -0.95470000 \\
\hline $\mathrm{H}$ & 1. 03654400 & -1.32967600 & -1.84728900 \\
\hline $\mathrm{C}$ & 2. 88531900 & 0.20468100 & 1. 18155500 \\
\hline $\mathrm{H}$ & 0.93012100 & 0.65165700 & 1. 95328600 \\
\hline $\mathrm{C}$ & 3. 61823300 & -0.35364700 & 0.13372600 \\
\hline $\mathrm{H}$ & 3. 50854600 & -1.34497000 & -1.77362900 \\
\hline
\end{tabular}




$\begin{array}{rrrr}\mathrm{H} & 3.39879000 & 0.62942600 & 2.03713700 \\ \mathrm{H} & 4.70186200 & -0.35941600 & 0.16831400 \\ \mathrm{C} & -1.03904800 & 2.16989900 & -0.14534200 \\ \mathrm{H} & -1.75930000 & 2.90485500 & 0.20918400 \\ \mathrm{C} & 0.08425600 & 2.63279800 & -0.70227300 \\ \mathrm{H} & 0.85186300 & 1.98869800 & -1.10979800 \\ \mathrm{H} & 0.25777400 & 3.70105200 & -0.76657400 \\ \mathrm{H} & -4.56189200 & -0.75986400 & 0.17880000\end{array}$

